\title{
Sistem Pendukung Keputusan Perekrutan Karyawan PT. Cakra Mobilindo Menggunakan Metode Simple Additive Weighting
}

Aditya Rizky Pratama, Ismarmiaty

Universitas Bumigora, Indonesia

\begin{tabular}{l} 
Article Info \\
\hline Article history: \\
Received, 28 July 2020 \\
Revised, 21 August 2020 \\
Accepted, 8 September 2020 \\
\hline
\end{tabular}

\section{Kata Kunci:}

Perekrutan Karyawan Sistem Pendukung Keputusan Simple Additive Weighting Sumber Daya Manusia Website

\begin{abstract}
ABSTRAK
Penelitian ini bertujuan untuk membantu proses seleksi rekrutmen calon karyawan Perseroan Terbatas (PT) Cakra Mobilindo dengan menerapkan metode Simple Additive Weighting. Kendala yang dimiliki yaitu proses pendataan manual, aspek penilaian yang beragam, dan kebutuhan sumberdaya yang besar. Alternatif solusi yang ditawarkan adalah membangun sebuah sistem pendukung keputusan yang dapat melakukan seleksi terhadap data calon karyawan dengan mengautomatisasi pengumpulan data, pengolahan data dan distribusi informasi sehingga memudahkan pihak perusahaan untuk dapat mengelola data dan nilai hasil tes calon karyawan sesuai dengan kriteria yang sudah ditetapkan. Metode Simple Additive Weighting memiliki konsep dasar mencari penjumlahan terbobot dari rating kinerja pada setiap alternatif pada semua atribut. Tahapan penelitian terdiri dari analisis masalah, pengumpulan literatur, desain sistem, implementasi, dan pengujian. kesimpulan bahwa aplikasi mempermudah manager dalam mengambil keputusan pemilihan calon karyawan dan sistem dapat mempermudah pendaftaran karyawan pada PT. Cakra Mobilindo sebesar $100 \%$ dan membantu pelamar untuk melakukan proses rekrutmen calon karyawan sebesar $82,5 \%$
\end{abstract}

\section{ABSTRACT}

Keywords:

Employee Recruitment Decision Support System Simple Additive Weighting Human Resources

Website collection process, various aspects of the assessment, and the need for large
This study aims to assist the recruitment selection process for prospective employees of Cakra Mobilindo Limited Company (Ltd) by applying the Simple Additive Weighting method. Constraints that are owned are the manual data resources. The alternative solution offered is to build a decision support system that can select prospective employee data by automating data collection, data processing and information distribution, making it easier for companies to manage data and test results for prospective employees according to predetermined criteria. The Simple Additive Weighting method has the basic concept of finding the weighted sum of the performance ratings for each alternative on all attributes. The research stages consisted of problem analysis, literature review, system design, implementation, and testing. The conclusion is that the application makes it easier for managers to make decisions about selecting prospective employees and the system can simplify employee registration at Cakra Mobilindo, Ltd by $100 \%$ and assists applicants in the recruitment process for prospective employees by $82.5 \%$

This is an open access article under the CC BY-SA license.

\section{Penulis Korespondensi:}

Ismarmiaty,

Program Studi Ilmu Komputer,

Universitas Bumigora.

Email: ismarmiaty@universitasbumigora.ac.id 


\section{PENDAHULUAN}

Pengelolaan Sumber Daya Manusia (SDM) dari suatu perusahaan mempengaruhi banyak aspek penentu keberhasilan kerja dari perusahaan tersebut. [1] Salah satu dari pengelolaan SDM adalah perekrutan karyawan dalam sebuah perusahaan. Penelitian ini [2] menjelaskan bahwa rekrutmen merupakan suatu keputusan perencanaan manajemen sumber daya manusia mengenai jumlah karyawan yang dibutuhkan, kapan diperlukan, serta kriteria apa saja yang diperlukan dalam suatu organisasi. Pentingnya melakukan rekrutmen telah dianalisis berdampak pada kinerja perusahaan secara langsung. Beberapa penelitian terkait pengaruh seleksi karyawan dengan kinerja perusahaan antara lain oleh penelitian [2] terkait dengan Pengaruh Proses Rekrutmen dan Seleksi Terhadap Kinerja Karyawan pada PT. Bank Sulutgo. Penelitian lainnya [3] yang melakukan penelitian terkait dengan Pengaruh dan Seleksi terhadap Kinerja Karyawan PT. Telkom Indonesia, Tbk. Cabang Sidoarjo. Penelitian sejenis [4] terkait dengan Pengaruh Rekrutmen dan Seleksi terhadap Kinerja dan penelitian [5] terkait dengan Pengaruh Proses Rekrutmen (Porek) dan Seleksi terhadap Kinerja Karyawan PT. Bank Maya Pada Internasional. Masing-masing penelitian tersebut menyimpulkan bahwa terdapat pengaruh signifikan terhadap rekrutmen dan seleksi terhadap kinerja perusahaan. Dari kesimpulan tersebut maka dapat peneliti dapat melihat pentingnya melakukan rekrutmen dalam memilih karyawan yang akan bergabung dalam sebuah perusahaan. Hasil rekrutmen diharapkan dapat memberikan hasil yaitu pegawaipegawai baru yang dapat bekerja dan atau bekerja sama untuk dapat mencapai tujuan perusahaan. Penelitian [] dalam Peneltian [7] menyatakan bahwa tanpa adanya kualitas dan performa seorang karyawan yang baik dalam suatu perusahaan, maka akan sulit bagi perusahaan untuk mendapatkan hasil yang optimal dalam menjalankan perusahaan.

PT. Cakra Mobilindo merupakan suatu badan usaha (perusahaan) yang bergerak di bidang penjualan kendaraan Roda Empat (R-4) dengan merek Suzuki. PT. Cakra Mobilindo memiliki empat bagian pelayanan terhadap konsumennya yaitu Sales, Service, Sparepart dan Body Repair dalam rangka mendukung pelayanan Agen Tunggal Pemegang Merek (ATPM) di area NTB. Saat ini PT. Cakra Mobilindo telah berkembang pesat seiring dengan semakin berkembangnya iklim dunia usaha. Kebutuhan akan tenaga kerja atau sumber daya manusia yang handal meningkat, sehingga proses seleksi atau pemilihan terhadap calon karyawan baru akan semakin meningkat. Proses pendaftaran dan pemilihan calon karyawan pada PT. Cakra Mobilindo saat ini masih dilakukan secara manual sehingga calon karyawan yang ingin mendaftar harus datang langsung ke pihak Perusahaan. Banyaknya aspek atau kriteria yang ditetapkan oleh pada pemilihan calon karyawan membuat perhitungan nilainya menjadi lebih sulit. Melihat hal tersebut, perlu adanya suatu sistem pendukung keputusan berupa pengolahan data perekrutan karyawan yang terkomputerisasi secara optimal agar lebih efektif dan efisien.

Sistem Pendukung Keputusan (SPK) merupakan proses dari sistem informasi berbasis komputer yang digunakan suatu organisasi atau perusahaan untuk mendukung pengambilan keputusan [] $]$. SAW Merupakan metode penjumlahan terbobot. Metode SAW ini membutuhkan proses normalisasi matriks keputusan (X) ke suatu skala yang dapat di perbandingkan dengan semua rating alternatif yang ada [9]. Metode SAW mengenal adanya 2 (dua) atribut yaitu kriteria keuntungan (benefit) dan kriteria biaya (cost). Perbedaan mendasar dari kedua kriteria ini adalah dalam pemilihan kriteria ketika mengambil keputusan[8], [10]. Metode SAW sering digunakan untuk data yang tidak stabil dan berubah-ubah sehingga diperlukan analisis sensitivitas. Hal ini dikarenakan metode SAW memungkinkan pembuat keputusan untuk mengubah kepentingan dari nilai atribut [11]. Kelebihan dari model Simple Additive Weighting (SAW) dibandingkan dengan model pengambilan keputusan yang lain terletak pada kemampuannya untuk melakukan penilain secara lebih tepat karena di dasarkan pada nilai kriteria dan bobot preferensi yang sudah ditentukan, selain itu SAW juga dapat menyeleksi alternatif yang ada karena adanya proses perankingan setelah menentukan nilai bobot untuk setiap atribut. [12] Beberapa penelitian sejenis yang terlah dilakukan sebelumnya pada bidang yang sama antara lain dalam penelitian [13] terkait dengan sistem pendukung keputusan penerimaan karyawan dengan metode Analitical Hierarchy Process (AHP) dan Simple Additive Weighting (SAW) (studi kasus: PT. Young Tech Mekar). Penelitian [14] terkait dengan Sistem Pendukung Keputusan Penerimaan Karyawan Dengan Metode Simple Additive Weighting (SAW). Penelitian [15] terkait dengan Penerapan Metode Simple Additive Weighting (SAW) dalam Seleksi Calon, dan penelitian [16] Sistem Pendukung Keputusan Penerimaan dan Penilaian Karyawan Warehouse dengan Aplikasi Web. Kelebihan penelitian yang dilakukan yaitu aplikasi yang dikembangkan berbasis website ini tidak hanya menyelesaikan masalah rekrutmen dan memberikan hasil terkait dengan seleksi yang dilakukan namun memberikan akses kepada calon karyawan untuk dapat menginput database terkait dengan lamaran yang diajukan dan melihat informasi seleksi secara langsung melalui website. 


\section{METODE PENELITIAN}

\subsection{Tahapan Pengembangan Aplikasi}

Tahapan pengembangan aplikasi terdiri dari beberapa tahapan antara lain analisis permasalahan yang dihadapi dalam penelitian, pengumpulan literatur terkait dengan penelitian yang akan dilaksanakan, lalu desain aplikasi hingga implementasi dan pengujian dari penerapan metode Simple Additive Weighting (SAW) pada aplikasi dalam penelitian ini. Tahapan-tahapan tersebut digambarkan pada Gambar 1.

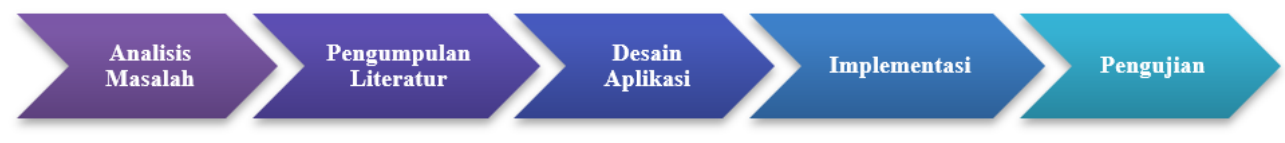

Gambar 1. Tahapan Pengembangan Aplikasi

\subsection{Sistem Pendukung Keputusan}

Sistem Pendukung Keputusan (SPK) atau yang disebut Decision Support System (DSS) adalah bagian dari sistem informasi berbasis komputer yang digunakan suatu organisasi atau perusahaan untuk mendukung pengambilan keputusan. SPK digunakan untuk mengambil keputusan dengan data yang begitu banyak. Untuk itu SPK yang efektif adalah memanfaatkan keunggulan unsur manusia dan perangkat elektronik. Menggunakan komputer yang terlalu banyak akan menghasilkan keputusan yang bersifat mekanis, tidak fleksibel. Sedangkan menggunakan manusia terkadang akan menghasilkan keputusan yang lamban, selain itu pemanfaatan data yang serba terbatas [] $]$.

\subsection{Simple Additive Weighting}

Metode Simple Additive Weighting (SAW) sering juga dikenal istilah metode penjumlahan terbobot. Konsep dasar metode SAW adalah mencari penjumlahan terbobot dari rating kinerja pada setiap alternatif pada semua atribut. Metode SAW membutuhkan proses normalisasi matriks keputusan (x) ke suatu skala yang dapat diperbandingkan dengan semua rating alternatif yang ada [17].

Metode SAW membutuhkan proses normalisasi matriks (x) pada suatu skala yang dibandingkan dengan semua rating alternatif yang ada.[18] Berikut adalah langkah-langkah dari algoritma metode SAW:

1. Menentukan alternatif yang akan digunakan dalam penelitian, yaitu $\mathrm{A}_{\mathrm{i}}$.

2. Menentukan kriteria yang akan dijadikan sebagai instrumen pengambilan keputusan, yaitu $\mathrm{C}_{\mathrm{j}}$.

3. Menentukan bobot untuk setiap kriteria yang telah ditentukan, yaitu $\mathrm{W}_{\mathrm{j}}$.

4. Membuat tabel rating kecocokan dari setiap alternatif pada setiap kriteria.

5. Membuat matriks keputusan ( $\mathrm{x}$ ) dari tabel rating kecocokan yang telah dibuat sebelumnya.

6. Perhitungan normalisasi dari matrik keputusan (x) menggunakan persamaan (1)

$$
r_{i j}=\left\{\begin{array}{cl}
\frac{x_{i j}}{\operatorname{Max}_{i}\left(x_{i j}\right)} & \text { Jika j adalah kriteria } \\
\text { keuntungan (benefit) } \\
\frac{\operatorname{Min}_{i}\left(x_{i j}\right)}{x_{i j}} & \text { Jika j adalah kriteria } \\
\text { biaya (cost) }
\end{array}\right.
$$

Pada persamaan (1) dijelaskan bahwa $\mathrm{r}_{\mathrm{ij}}$ adalah nilai rating kinerja ternomalisasi, dimana $\mathrm{x}_{\mathrm{ij}}$ adalah nilai atribut yang dimiliki setiap kriteria, lalu variable Max $\mathrm{x}_{\mathrm{ij}}$ adalah nilai terbesar dari setiap kriteria dan Min $\mathrm{x}_{\mathrm{ij}}$ adlah nilai terkecil dari setiap kriteria dengan variabel $\mathrm{r}_{\mathrm{ij}}$ adalah rating kinerja ternomalisasi dari alternatif $A_{i}$ pada atribut $C_{j}, i=1,2,3,4, \ldots, p$ dan $j=1,2,3,4, \ldots, q$.

7. Hasil normalisasi matrik keputusan (x), membentuk setiap alternatif matrik keputusan ternomalisasi (R).

8. Perhitungan nilai prefensi $\left(\mathrm{V}_{\mathrm{i}}\right)$ untuk setiap alternatif yaitu dengan penjumlahan perkalian matrik ternomalisasi $\mathrm{R}$ dengan vektor bobot dengan menggunakan persamaaan (2). Persamaan tersebut memiliki beberapa variabel antara lain adalah $\mathrm{v}_{\mathrm{i}}$ yang merupakan ranking untuk setiap alternatif, sedangkan $\mathrm{w}_{\mathrm{j}}$ adalah nilai bobot dari setiap kriteria dan $r_{i j}$ adalah nilai rating inerja ternomalisasi. Hasil dari persamaan bahwa nilai $v_{i}$ yang paling besar mengindikasi bahwa alternatif $A_{i}$ merupakan alternatif terbaik.

$$
V_{i}=\sum_{j=1}^{n} w_{j} r_{i j}
$$




\section{HASIL DAN ANALISIS}

\subsection{Identifikasi Masalah}

Tahapan prosedur rekrutmen terdiri dari beberapa tahapan, antara lain tahapan registrasi dan pengumpulan data, tahapan tes pertama, tes kedua, tes ketiga dan pengolahan nilai hingga pengumuman hasil seleksi yang dapat dilihat pada Gambar 2.

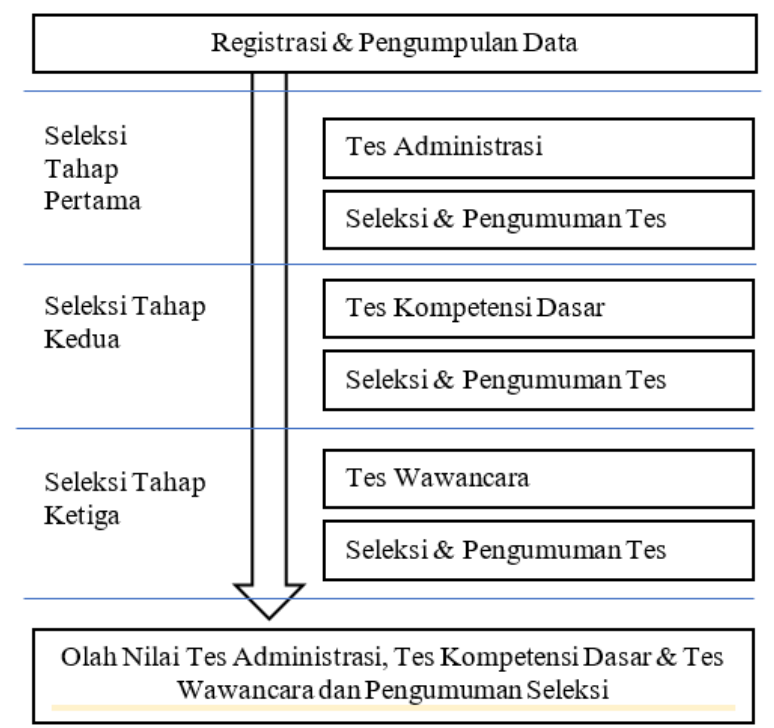

Gambar 2. Analisis Tahapan Prosedur Rekrutmen

Berdasarkan hasil wawancara yang telah dilakukan pada bagian perekrutan karyawan, dapat dipaparkan masalah yang terdapat pada proses perekrutan karyawan yang terdapat pada PT. Cakra Mobilindo yaitu sebagai berikut:

1. Proses pendaftaran masih dilakukan secara manual dengan mengharuskan pelamar melakukan proses lamaran di kantor PT. Cakra Mobilindo, selain itu pemberkasan data pelamar pekerjaan dilaksanakan dengan berbasis dokumen fisik yang tertumpuk. Hal tersebut dapat menyebabkan tumpukan data yang dapat hilang/ rusak atau terjadi kelalaian dari pihak bagian seleksi lamaran sehingga dapat merugikan pihak pelamar pekerjaan dan pihak perusahaaan dalam hal ini PT. Cakra Mobilindo.

2. Beragamnya aspek atau kriteria yang ditetapkan oleh pihak Perusahaan membuat perhitungan nilainya menjadi lebih sulit.

3. Proses pelaksanaan seleksi rekrutmen calon karyawan memerlukan waktu dan sumber daya, baik sumber daya manusia maupun sumber daya pendukung seperti dokumen dan kertas hingga alat komunikasi.

\subsection{Alternatif Solusi}

Alternatif solusi yang dapat diberikan dari permasalahan pada penelitian ini adalah dengan membangun sebuah sistem pendukung keputusan yang dapat melakukan seleksi terhadap data calon karyawan dengan mengautomatisasi pengumpulan data, pengolahan data dan distribusi informasi sehingga memudahkan pihak perusahaan untuk dapat mengelola data dan nilai hasil tes calon karyawan sesuai dengan kriteria yang sudah ditetapkan. Dengan digunakannya sistem pendukung keputusan diharapkan bahwa seleksi dapat dilakukan dengan waktu yang lebih singkat dan dengan hasil yang sebaik-baiknya.

\subsection{Penerapan metode Simple Additing Weight (SAW)}

Mengacu pada penelitian [18] bahwa penerapan metode SAW memiliki beberapa tahapan antara lain penentuan alternatif, penentuan kriteria dan bobot, penentuan sub kriteria dan bobot, penentuan rating kecocokan alternatif dengan matrik $\mathrm{x}$, normalisasi dengan matrik $\mathrm{R}$ hingga perangkingan alternatif. 


\subsubsection{Penentuan Alternatif}

Tabel 1. Alternatif

\begin{tabular}{cc}
\hline Kode & Nama Alternatif \\
\hline A1 & Deni Apriandi \\
A2 & Ronny Ikrar Dinata \\
A3 & Prabowo Saputro \\
A4 & Zulhaeri Hamdi \\
A5 & Husni Muaz \\
\hline
\end{tabular}

Penentuan Alternatif pada Tabel 1. merupakan langkah pertama yang dilaksanakan dalam penelitian bagian ini menentukan variabel $\mathrm{A}_{\mathrm{i}}$.

\subsubsection{Penentuan Kriteria dan Bobot}

Tabel 2. Kriteria dan Bobot

\begin{tabular}{cccc}
\hline Kode & Nama Kriteria & Sifat & Nilai Bobot \\
\hline C1 & IPK & Benefit & $10 \%$ \\
C2 & Tes Kompetensi & Benefit & $30 \%$ \\
C3 & Psikotes & Benefit & $20 \%$ \\
C4 & Tes Kemampuan Dasar & Benefit & $25 \%$ \\
C5 & Interview & Benefit & $15 \%$ \\
\hline
\end{tabular}

Langkah selanjutnya adalah melakukan penentuan kriteria sebagai variabel $\mathrm{C}_{\mathrm{i}}$ dan bobot kriteria sebagai variabel $\mathrm{w}_{\mathrm{i}}$ dari permasalahan yang diangkat seperti yag terlihat pada Tabel 2, pada penelitian terkait dengan rekruitmen pembobotan dilakukan pada kriteria Indeks Prestasi Kumulatif (IPK), Tes Kompetensi, Psikotes, Tes Kemampuan Dasar dan Interview. Masing telah diberikan nilai sifat yaitu benefit (sehingga menjadi nilai tambah pada sistem seleksi) dan tingkat nilai bobot dari masing-masing kriteria.

\subsubsection{Penentuan Sub Kriteria dan Bobot}

Langkah ketiga merupakan langkah untuk membobotkan lagi masing-masing kriteria yang memiliki sub kriteria, dapat dilihat pada Tabel 3 bahwa sub kriteria pada masing-masing kriteria dibagi menjadi menjadi 5 (lima) bagian sehingga permasing-masing sub kriteria memiliki bobot yang akan menguntungkan masingmasing alternatif.

Tabel 3. Sub Kriteria dan Bobot

\begin{tabular}{|c|c|c|}
\hline Kriteria & Sub Kriteria & Nilai Bobot \\
\hline \multirow{5}{*}{ IPK } & $3.6-4$ & 5 \\
\hline & $3.3-3.5$ & 4 \\
\hline & $3.0-3.2$ & 3 \\
\hline & $2.7-2.9$ & 2 \\
\hline & $2.5-2.6$ & 1 \\
\hline \multirow{5}{*}{ Tes Kompetensi } & $86-100$ & 5 \\
\hline & $76-85$ & 4 \\
\hline & $66-75$ & 3 \\
\hline & $51-65$ & 2 \\
\hline & $0-50$ & 1 \\
\hline \multirow{5}{*}{ Psikotes } & $86-100$ & 5 \\
\hline & $76-85$ & 4 \\
\hline & $66-75$ & 3 \\
\hline & $51-65$ & 2 \\
\hline & $0-50$ & 1 \\
\hline \multirow{5}{*}{ Tes Kemampuan Dasar } & $86-100$ & 5 \\
\hline & $76-85$ & 4 \\
\hline & $66-75$ & 3 \\
\hline & $51-65$ & 2 \\
\hline & $0-50$ & 1 \\
\hline \multirow{5}{*}{ Interview HRD } & Sangat Baik & 5 \\
\hline & Baik & 4 \\
\hline & Cukup & 3 \\
\hline & Kurang & 2 \\
\hline & Kurang Baik & 1 \\
\hline
\end{tabular}




\subsubsection{Memberikan Nilai Alternatif pada setiap Kriteria}

Tabel 4. Matrik X

\begin{tabular}{cccccc}
\hline \multirow{2}{*}{ Alternatif } & \multicolumn{5}{c}{ Nilai Setiap Kriteria } \\
\cline { 2 - 6 } & C1 & C2 & C3 & C4 & C5 \\
\hline A1 & 3 & 5 & 4 & 4 & 3 \\
A2 & 4 & 3 & 5 & 4 & 4 \\
A3 & 5 & 5 & 4 & 3 & 5 \\
A4 & 5 & 4 & 5 & 4 & 3 \\
A5 & 3 & 4 & 4 & 3 & 4 \\
\hline
\end{tabular}

Langkah yang dilaksanakan setelah melakukan pembobotan kriteria maupun sub kriteria, adalah memberikan nilai rating kecocokan dari setiap alternatif pada setiap kriteria. Hasil penilaian tersebut menghasilkan matriks keputusan seperti yang terlihat pada Tabel 4.

\subsubsection{Melakukan Normalisasi}

Setelah dilakukan penyusunan matriks keputusan sesuai dengan Tabel 4, maka dilanjutkan dengan normalisasi tabel Matrik X yang akan menghasilkan Matrik R seperti pada Tabel 5.

Tabel 5. Matrik R

\begin{tabular}{cccccc}
\hline \multirow{2}{*}{ Alternatif } & \multicolumn{5}{c}{ Nilai Setiap Kriteria } \\
\cline { 2 - 6 } & C1 & C2 & C3 & C4 & C5 \\
\hline A1 & 0.6 & 1 & 0.8 & 1 & 0.6 \\
A2 & 0.8 & 0.6 & 1 & 1 & 0.8 \\
A3 & 1 & 1 & 0.8 & 0.75 & 1 \\
A4 & 1 & 0.8 & 1 & 1 & 0.6 \\
A5 & 0.6 & 0.8 & 0.8 & 0.75 & 0.8 \\
\hline
\end{tabular}

\subsubsection{Melakukan Perangkingan}

Langkah terakhir adalah menghitung nilai prefensi $\left(\mathrm{V}_{\mathrm{i}}\right)$ untuk setiap alternatif yaitu dengan penjumlahan perkalian matrik ternomalisasi R dengan vektor bobot. Proses ini dapat dilihat pada Tabel 6 dengan tampilan daftar alternatif beserta nilai preferensi

Tabel 6. Perangkingan

\begin{tabular}{ccc}
\hline Alternatif & Nilai Preferensi & Ranking \\
\hline A1 & 0.86 & 3 \\
A2 & 0.83 & 4 \\
A3 & 0.90 & 1 \\
A4 & 0.88 & 2 \\
A5 & 0.77 & 5 \\
\hline
\end{tabular}




\subsection{Desain Sistem}

Desain sistem menggunakan konsep Unified Modeling Language (UML) dengan menggunakan 3 diagram yaitu usecase diagram, activity diagram dan class diagram sebagai penggambaran desain sistem.

\subsubsection{Use Case Diagram}

Usecase diagram digunakan untuk mengetahui fungsi yang ada di dalam sistem informasi dan penggunaan fungsi tersebut [19]. Usecase diagram dibuat untuk dapat memberikan informasi secara umum kepada user pengguna atau vendor terkait dengan case-case apa saja yang dapat dilakukan pada suatu aplikasi. Tampilan use case diagram dari aplikasi yang dibuat adalah pada Gambar 3. Terdapat 3 (tiga) aktor yaitu user (pelamar), admin dan manager yang berhubungan dengan sistem dengan masin-masing aktor memiliki case pada sistem yang dapat dilakukan.

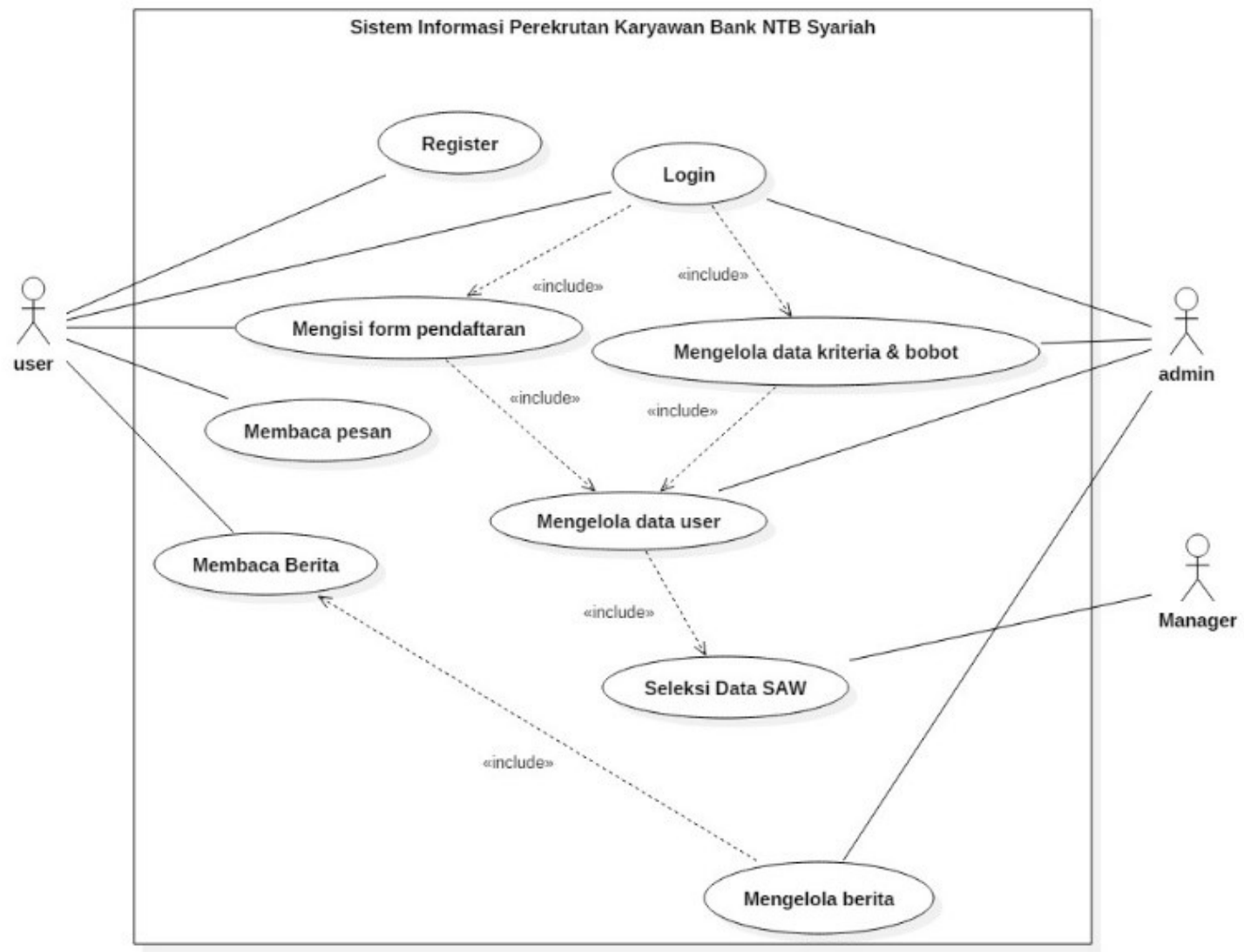

Gambar 3. Usecase Diagram

\subsubsection{Class Diagram}

Class diagram digunakan untuk menggambarkan struktur sistem dari segi pendefinisian kelas yang akan dibuat untuk membuat sebuah sistem [19]. Class Diagram pada Gambar 4 menjelaskan keterkaitan/ keterhubungan diantara kelas dalam sistem perekrutan karyawan di PT. Cakra Mobilindo. Struktur database dalam penelitian ini terdiri dari beberapa kelas antara lain kelas user, kriteria, bobot, sifat dan tahap. Selain itu terdapat kelas pendaftaran, tahap awal, tahap tes, interview, berita tahap akhir, nilai dan data. Keseluruhan kelas memiliki atribut dan perintah sesuai dengan fungsi kelas tersebut. 


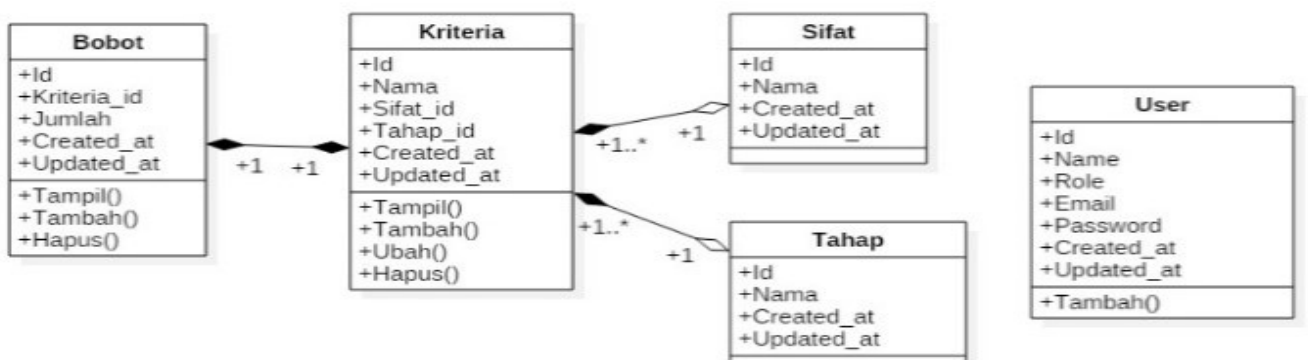

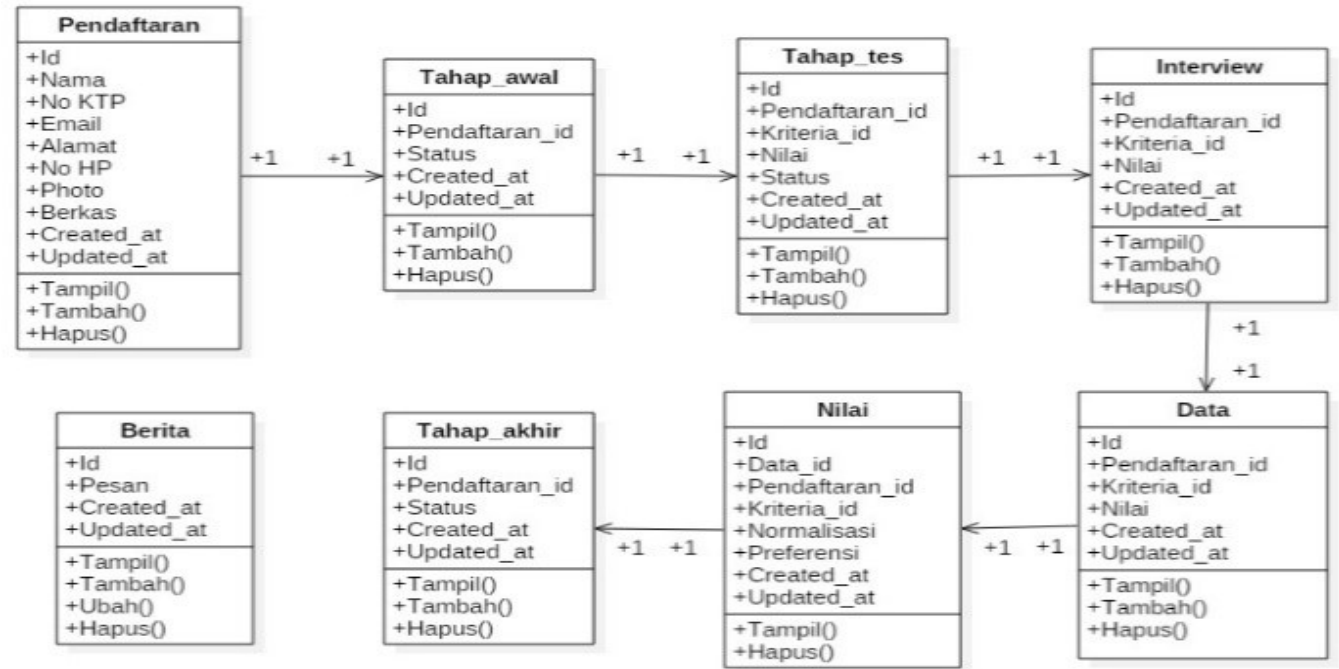

Gambar 4. Class Diagram

\subsection{Tampilan Aplikasi}

\subsubsection{Halaman List Pendaftar \& Penilaian Tes Administrasi}

Gambar 5 menampilkan Halaman List Pendaftar \& Penilaian Tes Administrasi. Daftar dari calon karyawan yang telah mendaftarkan diri dan menginput berkas-berkas persyaratan administrasi dapat dilihat dan diunduh untuk diperiksa oleh admin atau bagian seleksi. Bagian pelaksana seleksi calon karyawan dapat menentukan lolosnya calon karyawan ke tahapan selanjutnya dengan menekan tombol lolos/ tidak lolos. Hasil tersebut akan disimpan dan dapat dilihat oleh calon karyawan yang membuka akun masing-masing atau melihat portal berita dari seleksi yang dilaksanakan.

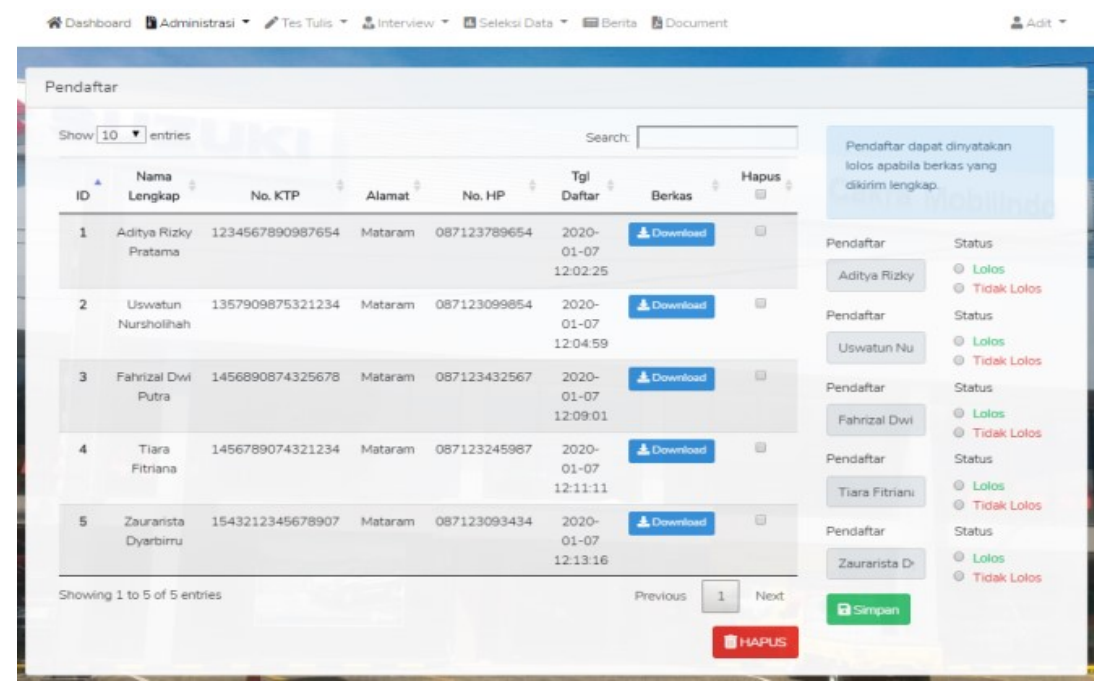

Gambar 5. Halaman List Pendaftar \& Penilaian Tes Administrasi

Matrik : Jurnal Manajemen, Teknik Informatika dan Rekayasa Komputer

Vol. 20, No. 1, September 2020: 117 128 


\subsubsection{Halaman Hasil Tes Kompetensi Dasar}

Tes kompetensi dasar merupakan salah satu tes yang dilaksanakan pada calon karyawan. Nilai tes calon karyawan ditampilkan di Gambar 7. Informasi yang ditampilkan adalah hasil tes calon karyawan beserta status kelulusan calon ke tahap selanjutnya. Hasil masukan ini akan disimpan dalam sistem untuk digunakan pada tahap akhir seleksi dengan menggunakan metode SAW.

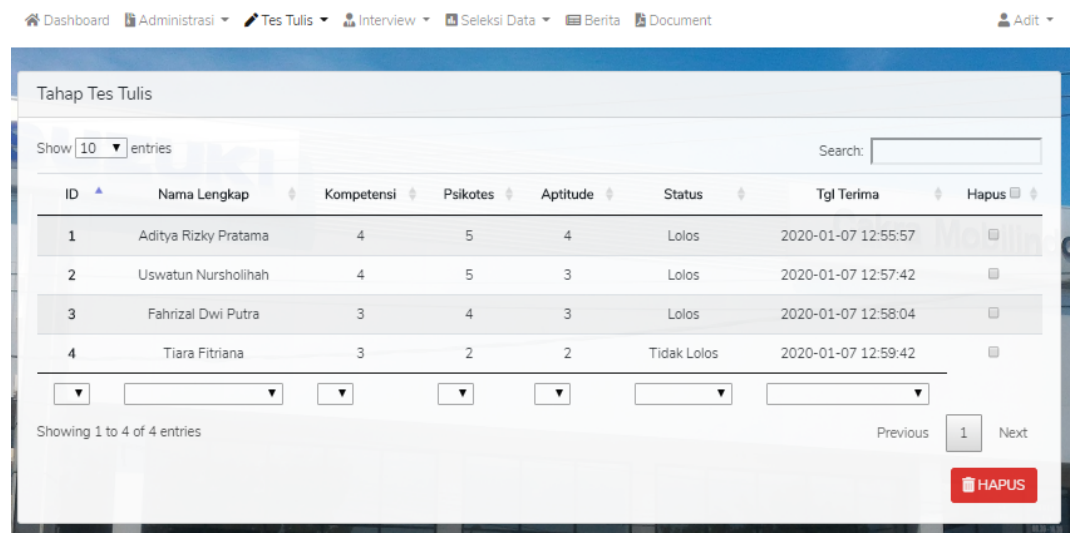

Gambar 7. Halaman Hasil Tes Kompetensi Dasar

\subsubsection{Halaman Hasil Tes Wawancara}

Tahapan terakhir yang dilaksanakan oleh calon karyawan adalah interview atau tahap tes wawancara. Hasil wawancara merupakan salah satu tahapan yang dibutuhkan untuk menentukan kelulusan calon karyawan. Tampilan hasil tes wawancara dapat dilihat pada Gambar 8. Masing-masing calon karyawan yang mengikuti tahapan ini akan diinputkan nilainya.

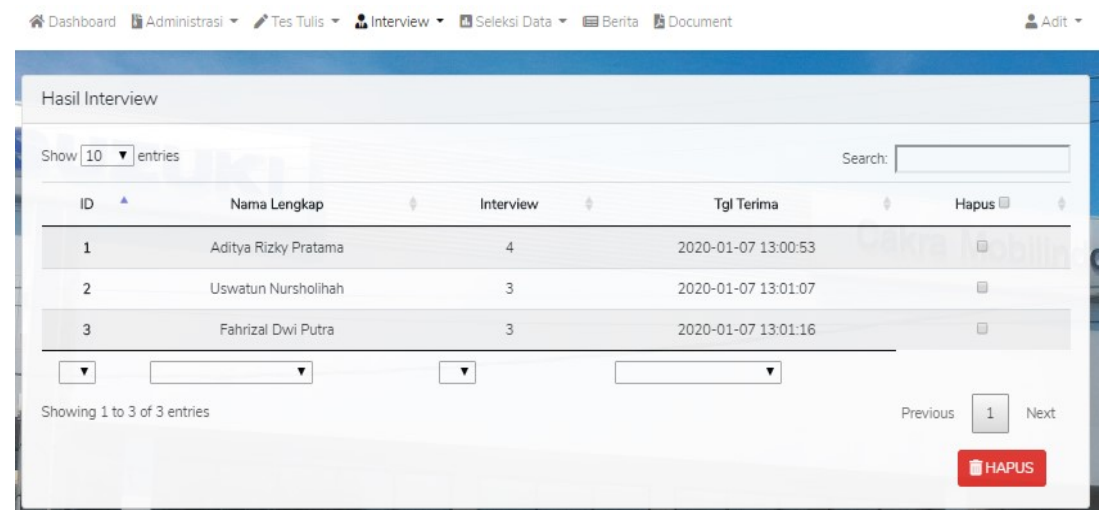

Gambar 8. Halaman Hasil Wawancara

\subsubsection{Halaman Hasil Seleksi}

Halaman hasil seleksi pada Gambar 9 memperlihatkan daftar peserta tes yang telah menyelesaikan tahapan tes hingga tahapan terakhir yaitu wawancara. Masing-masing tes akan dihitung dengan metode SAW dan menghasilkan nilai akhir yang secara otomatis oleh sistem akan berurutan dari nilai tertinggi hingga terendah. Mengacu pada konsep SPK, maka diberikan pilihan lolos dan tidak lolos yang akan digunakan oleh bagian seleksi/ pengambil keputusan untuk menentukan status tiap-tiap calon karyawan. Hasil akhir seleksi dapat dilihat pada halaman akhir di website yang juga disimpan dalam database. Hasil seleksi tersebut akan dapat diterima oleh calon karyawan dengan melihat pada layar pengumuman atau berita pada website yang dibuat. 


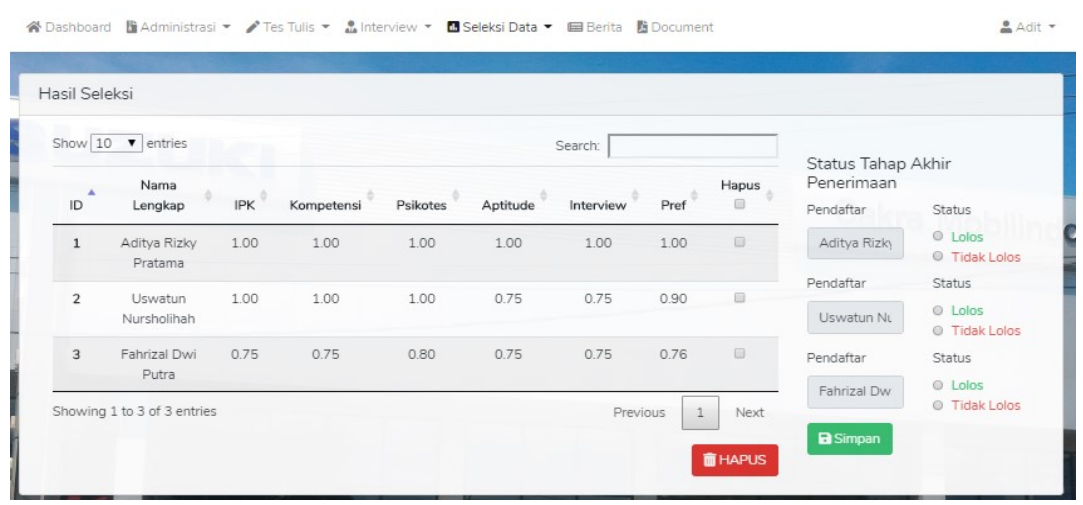

Gambar 9. Halaman Hasil Seleksi

\subsection{Pengujian}

Pengujian dilaksanakan dengan menggunakan pengujian sistem untuk mengetahui sistem yang direncanakan telah dibangun sesuai dan pengujian user terhadap sistem untuk mengetahui kemampuan sistem dalam memenuhi kebutuhan user. Pada pengujian sistem didapatkan hasil bahwa keseluruhan bagian sistem telah memenuhi rancangan sistem yang telah direncanakan dan pada pengujian user yang dilakukan terhadap dua tipe user yaitu: (1) $a d m i n$ dan (2) pengguna. Hasil dari kuisioner menjelaskan bahwa admin merasa setuju bahwa aplikasi dapat membantu perekrutan calon karyawan PT. Cakra Mobilindo dengan persentase 100\% dan sangat setuju bahwa aplikasi dapat membantu proses rekrutmen sebesar $40 \%$ sedangkan sisanya menyatakan setuju sebesar $42,5 \%$ dan netral sebesar $27,5 \%$.

\section{KESIMPULAN}

Berdasarkan penelitian dapat diambil kesimpulan antara lain: (1) penelitian telah berhasil membangun sistem pendukung keputusan untuk membantu user untuk dapat melakukan rekrutmen calon karyawan PT. Cakra Mobilindo berbasis teknologi website sesuai dengan kebutuhan yang telah disepakati antara peneliti dengan pengguna apikasi dan (2) Hasil pengujian user terhadap sistem memberikan kesimpulan bahwa aplikasi yang dibangun mempermudah manager dalam mengambil keputusan pemilihan calon karyawan dan sistem dapat mempermudah pendaftaran karyawan pada PT. Cakra Mobilindo sebesar 100\% dan membantu pelamar untuk melakukan proses rekrutmen calon karyawan sebesar $82,5 \%$.

\section{UCAPAN TERIMA KASIH}

Penulis mengucapkan terimakasih kepada Universitas Bumigora atas dukungannya dalam menyelesaikan penelitian yang penulis lakukan. Tidak lupa penulis juga mengucapkan terimakasih pada PT. Cakra Mobilindo yang sudah berkenan mengizinkan kami untuk melakukan penelitian di perusahaannya.

\section{REFERENSI}

[1] D. Zakaria and S. Mulyati, "Karyawan Terbaik pada PT . Mitra Sinergi Adhitama dengan Metode Simple Additive Weighting ( SAW ) Berbasis Desktop," Sistem Komputer dan Teknik Informatika, vol. 1, no. 2, pp. 611-617, 2018.

[2] B. R. Potale, V. Lengkong, and S. Moniharapon, "Pengaruh Proses Rekrutmen dan Seleksi Terhadap Kinerja Karyawan Pada PT Bank Sulutgo,” Jurnal Berkala Ilmiah Efisiensi, vol. 16, no. 04, pp. 453-464, 2016.

[3] H. Poernomo, "Pengaruh Rekrutmen dan Seleksi terhadap Kinerja Karyawan PT. Telkom Indonesia, Tbk. Cabang Sidoarjo," Journal of Management and Accounting, vol. 2, no. 1, pp. 87-101, 2019.

[4] T. A. Aziz, M. S. Maarif, and A. Sukmawati, "Pengaruh Rekrutmen dan Seleksi Terhadap Kinerja," Jurnal Aplikasi Bisnis dan Manajemen, vol. 3, no. 2, pp. 246-253, 2017.

[5] N. Aisyah and A. Giovanni, "Pengaruh Proses Rekrutmen ( Porek ) dan Seleksi terhadap Kinerja Karyawan," Jurnal Ekonomi \& Ekonomi Syariah, vol. 1, no. 2, pp. 8-18, 2018.

[6] R. Rachman, "Penerapan Metode Simple Additive Weighting (Saw) Pada Proses Penilaian Kinerja Karyawan," Tekno Insentif, vol. 4, no. 1, pp. 21-27, 2017.

[7] I. Y. Beti, "Karyawan Terbaik Menggunakan Simple Additive," ILKOM Jurnal Ilmiah, vol. 11, no. 3, pp. 252-259, 2019.

[8] R. Kurniati, B. Surarso, and F. Farikhin, "Sistem Pendukung Keputusan Penyeleksian Proposal Dana Menggunakan Metode AHP D Numbers,” Jurnal Sistem Informasi Bisnis, vol. 5, no. 1, pp. 9-18, 2015.

[9] R. Yanto, "Sistem Pendukung Keputusan Prioritas Investasi dalam upaya Peningkatan Kualitas Perguruan 
Tinggi," Jurnal RESTI (Rekayasa Sistem dan Teknologi Informasi), vol. 1, no. 3, pp. 211-216, 2017.

[10] F. Nugraha, B. Surarso, and B. Noranita, "Sistem Pendukung Keputusan Evaluasi Pemilihan Pemenang Pengadaan Aset dengan Metode Simple Additive Weighting (SAW), J Jurnal Sistem Informasi Bisnis, vol. 2, no. 2, pp. 67-72, 2016.

[11] R. L. Pradana, D. Purwanti, and A. Arfriandi, "Sistem Pendukung Keputusan Pemilihan Siswa Berprestasi Berbasis Website dengan Metode Simple Additive Weighting," Jurnal Sistem Informasi Bisnis, vol. 8, no. 1, p. 34, 2018.

[12] I. Aulia and Oktafianto, "Sistem Pendukung Keputusan Penerimaan Siswa Baru SMK Ma'Arif 01 Kalirejo Lam-Teng Menggunakan Metode Saw (Simple Additive Weighting)," Jurnal TAM (Technology Acceptance Model), vol. 2, no. 1, pp. 33-38, 2014.

[13] A. Budiman, "Sistem Pendukung Keputusan Penerimaan Karyawan dengan Metode Analitical Hierarchy Process (AHP) dan Simple Additive Weighting (SAW) (Studi Kasus: PT. Young Tech Mekar), " Universitas Pamulang, 2017.

[14] E. Ismanto and N. Effendi, "Sistem Pendukung Keputusan Penerimaan Karyawan Dengan Metode Simple Additive Weighting (SAW)," Sains dan Teknologi Informasi, vol. 3, no. 1, p. 1, 2017.

[15] N. Nuraeni, "Penerapan Metode Simple Additive Weighting (SAW) dalam Seleksi Calon Karyawan," Swabumi (Suara Wawasan Sukabumi) : Ilmu Komputer, Manajemen, dan Sosial, vol. 6, no. 1, 2018.

[16] I. Agus, F. Marisa, and I. D. Wijaya, "Sistem Pendukung Keputusan Penerimaan dan Penilaian Karyawan Warehouse dengan Aplikasi Web," Journal of Information Technology and Computer Science, vol. 2, no. 1, Jan. 2017.

[17] E. Jayanti, "Penerapan Metode Simple Additive Weighting dalam Sistem Pendukung Keputusan Perekrutan Karyawan (Studi Kasus: PT . Perkebunan Nusanta III Medan)," Pelita Informatika: Informasi dan Informatika, vol. 9, no. 3, pp. 149-154, 2015.

[18] T. Hidayat, F. Widiyanto, and Y. K. Hasim, "Rancang Bangun Support System Pemilihan Guru Terbaik Menggunakan Metode Simple Additive Weighting (SAW) (Studi Kasus: SMA Bhakti Pertiwi Kota Tanggerang)," Jurnal Teknik Informatika, vol. 5, no. 1, pp. 52-56, 2017.

[19] M. Shalahuddin and A. S. Rosa, Rekayasa Perangkat Lunak (Terstruktur dan Berorientasi Objek). Bandung: Informatika, 2013. 
